\title{
An Action Research Study from Implementing Flipped Classroom Model in Professional English Teaching and Learning

\author{
Xiao-Li SUN
}

\author{
Foreign Language Department of Shandong University of Business \& Technology, Yantai 264005, \\ China \\ happydonna@126.com
}

Key Words: FCM, learning interest, critical thinking

\begin{abstract}
This action research project implemented FCM in teaching Professional English to non-English majors, aiming at exploring whether FCM can increase the students' learning interest and develop their critical thinking. The study was conducted on a 16-week-semester basis and the instruments were a questionnaire, two oral tests and the teachers' journals. The result is positive. It seems not so difficult to sustain the students' motivation and engagement in FCM and implementing FCM does foster the students' critical thinking. However, the teachers do find the gap between the high achievers and low achievers is getting larger. The less-achieved students are getting worse at the end of the semester. Another point worthy to be mentioned is that the frequency of using newly learned vocabulary is much higher than that in conventional classroom.
\end{abstract}

\section{Introduction}

The latest edition of College English Teaching Guide(2015) makes clear that college English teaching is use-oriented. While developing the students' general English competence, the teachers should pay attention to improving the students' communication skills in academic English or professional English and developing their intercultural communication competence. College English Teaching Guide also explicitly proposes that the latest information technology should be vigorously integrated into college English teaching and diversified teaching and learning environment should be actively created. Accordingly, College English teachers are encouraged to use Micro-course online video, MOOC, etc., and to widen the teaching content by getting access to the rich online teaching resources as well. College English teachers are also advised to practice Flipped Classroom Model (FCM) and Blending Teaching Model, and online interaction platform and mobile learning platform are encouraged to be set up.

To answer the call of the Education Department and as a result of a survey among the sophomores, four English teachers decided to offer a course of Professional English in the fourth semester to meet the students' need and expectation. The course mainly aims to prepare the students for their future career while developing their English competence.

Till now, the research of FCM in other countries has focused on the application of the model while the research in China is primarily on the introduction of the theories (Liu Yan, 2016) and practices in College English teaching and learning are seldom reported. Therefore, the teachers decided to implement FCM teaching and learning to test its effects on Chinese non-English majors.

\section{Literature Review}

FCM is a technology-supported pedagogical innovation which has gained prominence only in the past few years. In 2007, Chemistry teachers Jonathan Bergman and Aaron Sams in Woodland Park High School upload their presentation and demo video to YouTube so that the students can study the knowledge before class and do exercises and ask questions in class. This is contrary to the conventional teaching procedure, so it is called "Flipped Classroom". There are different types of FCM, respectively being represented by Wood Park High School Model, Khan Academy Model, Riverside Unified School District Model, Harvard University Model, and Stanford University Model. Whatever type it is, in general, "FC is a blended learning model, targeting to exploit 
classroom time and space for appropriately designed interactive learning activities differentiated according to individual and group students' needs" (DeLozier \& Rhodes, 2017) and the shared major characteristic is to learn the knowledge before class and internalize the knowledge in class.

FCM can trace its root back to the following learning theories: Peer Instruction (Mazur, 1997), the Theory of Mastery Learning (Bloom, 1986), Self-access Learning Theory (Mitra, 1999), Humanism (Rogers, Stevick, etc.), Constructivism View of Learning (Vygotsky, Piaget, etc.) Game Learning Theory (Bowman, Driskell, etc.)

Studies have proved that FCM has produced various positive outcomes. FCM greatly enhances the students' learning engagement (Chen, Hsieh, Wu \& Marek, 2016; Jamaludin \& Osman, 2014) and by allowing students to "proceed at their own pace, guide themselves to additional content, and assess their own learning gains" (McLaughlin J. E., 2013), it also significantly promotes the students' learner autonomy. Moreover, with ample class time and the support of internet learning platform, collaborative learning activities and task-based learning activities are very suitable for FCM. A learning community is strongly recommended for its benefit of developing knowledge through constructive learning experiences, peer interaction and, collaboration (Wu, Chen, J. S., \& Yang, 2017) and many hail it an effective way to foster learners' critical thinking and to develop more positive learning attitudes in comparison with traditional teaching methods (Sun Rui, Meng \& Wen 2015; Gazi, 2009). Despite all the favor of FC, different voices may also be heard. The loss of motivation and engagement for blended course has been extensively discussed in literature (Fairchild, 2015; Holley \& Oliver, 2010) and how to maintain the students' motivation and engagement throughout the course has become a major concern.

\section{The Action Research Model}

The action research study follows Lewin's model which comprised of four stages: plan, act, observe, and reflect (Lewin, 1948, cited from Aidinopoulou, V., \& Sampson, D. G., 2017).

\section{Research Questions.}

Considering the above theory discussion, the research mainly answers two groups of questions: 1 . Does the implementation of FCM in Professional English promote the students' learning interest? Can the students maintain strong motivation throughout the practice? 2. Does the implementation of FC model foster the students' critical thinking?

\section{Subjects}

The participants of the study were over 600 sophomores from different majors: Finance, Accounting, Management, Engineering, Computer, Advertising, Math and Journalism. These students have already finished three semesters of general English study, but there are great diversities in their English proficiency.

\section{Procedure}

Plan (From January20 to February 25): make use of the winter holiday to make the teaching plan and videos.

Act and observe (From Febuary27 to June16): implement FCM and collect data.

Reflect (June 17-25): Reflect on the model by analyzing the questionnaires, two oral tests and the teachers' observation.

\section{Project Context}

The study was conducted on a semester basis (16 weeks, two hours each week). The course syllabus covers six units: Preparing for the Challenges, Getting the Job, Relocating for Work, Doing the Job, Solving Problems and Business Negotiation. "Voluntariness is a prerequisite for independent language learning"(Lee, 1998), so the advantages of FCM were lectured at the very beginning of the semester to gain the students' recognition. Autonomous learning skills and necessary computer skills are also trained to help the students better survive the project. 


\section{Teaching Design}

Pre-class: different assignments are allocated before class according to the content of the units. Watching videos before class is essential to the Model, so all the teachers repeatedly emphasize this point. Most videos are made by the teachers and some are selected from the online resources but edited by the teachers. No video is more than twenty minutes so that the students' focus may not be diverted and key points may be well digested. The subjects of the videos may be various, from content to form. Besides watching the videos, the students may also be required to perform other tasks, such as preparing a presentation on interview etiquettes or a role play on purchasing clothes in a store, etc. Community on line and learning groups are formed to promote collaborative learning. The students may post their questions in the community and expect help from their peers. Teachers also give feedbacks if really necessary. Language points are required to be grasped before class.

In-class: the teachers check the grasping of the new words through a great variety of activities, such as reading the new words, guessing the meaning by doing games, telling a story by using the words, taking turn to make sentences by using one of the word, citing famous quotes including the words, etc. Class activities targeting developing all the four basic language skills, whereas more stress is laid on the productive skills of speaking and writing. Therefore, a great many activities like presentation, debate, role-play, discussion, and so on are organized in class. To develop the students' critical thinking skills, discussion questions are specially designed. For instance, if there is such a question as "how do you understand the remark 'It's not how many times you fall down that matters. It's how many times you get back up that makes success!'?" there will also be one to facilitate the students to view the subject in another perspective "do you agree that there are times when it's simply better to give up?"

After-class: Writing assignments are given and corrected by both the teachers, peers and the computers. Various practical projects are also conducted, such as inviting a HR manger to give a job interview, working as volunteers at Trade Fairs, working as assistants in a Cafe, etc.

Under the requirement of the university, there is a final test, but it only accounts for $50 \%$ of the total scores. The students' daily performance is assessed not only by the teachers but also by group leaders as well as other group members. The computer will tell whether a student has done the online assignments, and show his or her study time online. The group leaders play an important part because they keep a clear record of each member's response in the community and his or her contribution to their team work. Inter-evaluation among groups will also be calculated.

\section{Instruments.}

The instruments are composed of a questionnaire, two oral tests, and the teachers' journals. The two oral tests primarily aim to evaluate the students' critical skills. Because too many factors may affect the final test's result, the final test is left out of account due to its possible invalidity.

\section{Data Collection and Analysis}

621questionaniares were handed out at the end of the semester and 609 of them were valid. According to the statistics, $76 \%$ students agree that the course achieve their objective of making preparations for their future career and claim that they get to know something about their future profession. 82\% students hold that the course increases their interest in English, which is in accord with Sun, Meng \& Wen's result that 91\% students believe watching the videos arouse their interest in learning English (2015). It must be pointed out that this course is offered to satisfy the students' demand, which may have a positive influence on their choice. $41 \%$ find it difficult to keep up with the course and $17 \%$ admit sometimes they want to drop out. That shows that even though they are enthusiastic about the course, some students still find it demanding to regulate themselves, so measures should be taken to sustain their motivation. 94\% students always watch the video before class or do it quite often and 37\% even watch it more than once, which indicates that most students have the initiative and autonomy. 92\% think they spend more time in English study than before, from which the same conclusion as Chen, Wu \& Marek's (2016) can be drawn: FCM enhances the students' engagement. If they want to keep pace with the course, the students have to do a lot of 
work before class. Thanks to the process appraisal system, even the less self-disciplined may have to finish their assignments on time. 89\% students state that FCM helps foster critical thinking, which is in line with Sun, Meng \& Wen's( 2015) and Gazi, 2009)'s research. The statistics is proved by the second oral test during which $78 \%$ students looked at things more dialectically than in the first one which was taken before the application of the FCM.

The teachers' journals reveal some other findings: the gap between the students are getting larger and the less-achieved students' performance is getting poorer. In each class there are several unpopular students who fail to watch the videos before class and cannot keep up with the class activities. Many factors contributing to this problem. Some of these students may not be able to get access to a computer or they cannot afford to connect their mobile phone with a net. Some of them may just lack the interest and motivation to learn and others may find it hard to get accustomed to a new learning model because of their conventional English learning history. The teachers once thought about requiring the students to watch the video on line so that their watch time may be recorded, but they dropped the idea because it was too expensive to watch videos on a cell phone since many students did not have a PC. The positive result is that the class is really learner-centered and students 'talk time in class is much longer than the teachers'. In addition, because they do a lot of preview work, the frequency of using newly learned words in class activities is much higher than that in a traditional classroom.

\section{Result}

From the above analysis, it can be seen that implementing FC model in Professional English class is effective and produces many positive outcomes. The students have not only become autonomous learners and more critical thinkers, but also have increased their learning interest in English and improved their communication competence while grasping some professional knowledge. Loss of motivation and engagement is not a serious problem in this research although a small number of students do have trouble with self-accessed learning due to various reasons.

\section{Suggestions.}

1. The successful implementing of FCM depends to a large extent on a good information support environment, hence needs support from the university authority. The University should provide such software systems as: micro-video release system, interactive system, intelligent knowledge diagnosis system, remote support and service system, statistical systems and management system (Zhao, 2014). Besides, each student must have a computer or terminal that can be connected to the Internet and it is better for free considering the economic condition of some students. In addition, the server must have sufficient capacity as well as concurrency capability and the network bandwidth must be able to guarantee the normal operation of the micro-video.

2. During the practice of FCM, formalism should be avoided. The teachers should not simply invert the order of teaching steps, which means asking the students to watch the video before class and leave the classroom a free-talk forum or simply repeat the video's content in class. Class activities must be well-designed so that it can rouse the students' enthusiasm and be in line with their cognitive psychology.

3. The project is very demanding for the teachers because they expend a great deal of time and energy preparing materials, making videos, designing activities and giving feedbacks. However, they are primarily appraised by their research work and have to meet the research quota, so it is hoped that their teaching work may be fairly evaluated.

4. It is a heavy load for the students to watch the video, prepare supplementary materials and do the team work before class, so the students' autonomy and initiative have a strong impact on the effect of the effectiveness of FCM. An objective and scientific evaluating system must be set up to supervise and assess their activities before class as well as in class. Moreover, awareness of active participation in activities should be energetically cultivated. If possible, time-management skills should also be instructed to low-achievers to help them be self-controlled.

5. Videos had better be short and attractive, only highlighting key points and difficulties and not covering everything. Otherwise the students will become impatient and decide to give up half-time 
or simply not watch it.

\section{Conclusion}

The action research of practicing FCM in teaching and learning Professional English demonstrates that FCM can enhance the students' interest and engagement in learning and foster their critical thinking. The frequency of using newly learned words also rises compared with that in a conventional classroom. Although the gap between the high performers and low achievers are widened, there are only a small number of less achieved students who have trouble in regulating themselves. However, this research is only conducted in one university and the sample is limited. Therefore, future work will be needed to investigate these findings on a larger scale.

\section{References}

[1] Liu,Yan, Research on Construction of Flipped Classroom Model For Vocabulary Instruction and Its effectiveness: based on Teaching Practice of Three Colleges, TEFLE. 167(2016) 43-49.

[2] DeLozier, S. J., \& Rhodes, M. G., Flipped classrooms: A Review of key ideas and recommendations for practice, Educational Psychology Review. 29 (2017) 141-151.

[3] Mazur E., Peer Instruction: A user's Manual, Upper Saddle River, NJ, Prentice Hall, 1997.

[4] Mitra S., Self-organizing system for mass computer literacy: Findings from the "Holes in the Walls" experiments, International Journal of Development Issues. 4 (2005) 71-81.

[5] Chen Hsieh, J. S., Wu, W.-C. V., Marek, M. W., Using the flipped classroom to enhance EFL learning, Computer Assisted Language Learning. (2016) 1-21. doi:10.1080/09588221.2015.1111910

[6] Jamaludin, R., \& Osman, S. Z. M the Use of a flipped classroom to enhance Engagement and promote active learning, Journal of Education and Practice. 2 (2014) 124-131.

[7] McLaughlin, J. E., Griffin, L. M., Esserman, D. A., Davidson, C. A., Glatt, D. M., .Roth, M. T., Gharkholonarehe, N., \& Mumper, R. J. , Pharmacy student engagement, performance, and perception in a flipped satellite classroom, American journal of pharmaceutical education. 77 (2013), Article 196, doi: 10. 5688/ajpe779196

[8] Wu, W.-C. V., Chen Hsieh, J. S., \& Yang J. C., Creating an Online Learning Community in a Flipped Classroom to Enhance EFL Learners' Oral Proficiency, Educational Technology \& Society. 20 (2017) 142-157.

[9] Sun, Rui, Meng, Wensen \& Wen Xuan, the Application of Flipped Classroom in TCSL, Language Teaching and Linguistics Studies. 3 (2015) 34-39.

[10] Gazi, Z. A., Implementing constructivist approach into online course designs in Distance Education Institute at Eastern Mediterranean University, The Turkish Online Journal of Educational Technology. 8 (2009) 68-81.

[11] Holley, D. and Oliver, M., Student engagement and blended learning: Portraits of risk, Computers \& Education. 54 (2010) 693-700.

[12] Aidinopoulou, V., \& Sampson, D. G., An Action Research Study from Implementing the Flipped Classroom Model in Primary School History Teaching and Learning, Educational Technology \& Society. 20 (2017) 237-247.

[13] Lee, Icy, Supporting Greater Autonomy in Language Learning, ELT Journal. 52 (1998) 282-291.

[14] Zhao, Xinglong, The Design of Teaching Model Based on Knowledge Construction in Flipped 
Classroom, Modern Distance Education Research. 128 (2014) 55-61. 